\title{
SUKARNO AND HATTA: THE GREAT DEBATE IN INDONESIA
}

\author{
JUSTUS M. VAN DER KROEF
}

From September 10 to 14,1957 , a National Congress convened in Djakarta, Indonesia, for the purpose of reviewing the many problems of provincial separatism, political instability, and economic stagnation that have plagued the young Republic for the past two years. ${ }^{1}$ Perhaps the most important result of the widely heralded gathering, which was attended by political, military, and religious leaders from all the major areas in the country, was a joint statement issued by President Sukarno and former Vice-President Mohammad Hatta. In this declaration these "two "grand old men" of the Indonesian Revolution, who, for some time now, have been at odds with each other over the future course of their nation, pledged themselves anew "to continue to participate with all the people of Indonesia, with the Government of the Republic of Indonesia, and with all the organs of authority of the state in caring for and defending the principles of the Independence Proclamation of August 17, 1945, under whatever circumstances." ${ }^{2}$ Since much of the political dissension in Indonesia has been attributed to the rift in what is commonly referred to as the dwitunggal (duumvirate, i.e., the joint national leadership of Hatta and Sukarno), evidenced by Hatta's resignation as Vice-President late in 1956 and by his increasingly vehement criticisms of Sukarno's policies, the joint statement was hailed widely as a step in the direction of that national unity and purpose which Indonesia so badly requires.

Yet, it is difficult to suppress the suspicion that no mere handshake or signature under a euphonious policy statement will necessarily restore harmony between far-reaching and bitterly

\footnotetext{
* The author was born and largely educated in Indonesia. Ph.D. (Columbia University). Formerly Professor of $x^{7}$ oreign Studies, Michigan State University, presently Professor of Sociology, University of Bridgeport, Connecticut, U.S.A. Returned twice to Indonesia for extensive research trips since the second world war. Author of many articles on Indonesia and of Dutch Policy in Indonesia: A History and Perspective (Ann Arbor, 1953); Indonesia in the Modern World, 2 vols. (Bandung, Indonesia, 1954-56), and Indonesian Social Evolution. Some Psychological Considerations (Amsterdam, 1958).

I On these problems see J. M. van der Kroef: "The Place of the Army in Indonesian Politics," Eastern World (London), Vol. 11 (January, 1957), pp. 13-18; "Instability in Indonesia," Far Eastern Survey (New York), Vol, 26 (1957), Pp. 49-62; and "Guided Democracy in Indonesia," Far Eastern Survey, Vol. 26 (1957), pp. 113-124.

2 Antara Daily Newsbulletin, September 18, 1957, p. 1.
} 
antagonistic trends of opinion in the Indonesian body politic, trends of which Sukarno and Hatta have become the principal symbolic expressions. It is not just the dwitunggal which in the opinion of most observers requires restoration, but rather the cooperation between what each member of the duumvirate has come to represent needs to be re-established. The problem has become all the more urgent since the proclamation of the revolutionary "Republic of Indonesia" in Sumatra on February 15, 1958. The dialogue between Sukarno and Hatta in this sense reaches to the very foundations of the Indonesian Republic, and touches upon the structure and character of its government, its economic policies, and international relations. There is thus far little indication that Indonesia's "great debate" has moved toward some common resolve on these vital issues. It may, therefore, perhaps be useful to point out where the principal areas of disagreement lie and what types of individuals and groups in Indonesian life have come to cluster around each opposing pole of the dwitunggal.

\section{I}

In their own origin Sukarno and Hatta reflect much of the debilitating antithesis that besets their country. Though his mother was Balinese, Sukarno was born into a typical family of the lesser Javanese aristocracy, long the mainstay of public administration, and his early education and initial professional ambitions were permeated by the cultural traditions of his class. Hatta, on the other hand, is a Menangkabau, a product of Central Sumatra, where aristocratic traditions are weak and have long been contested by the inroads of uncompromising Islamic orthodoxy and by a rising class of merchants and petty industrialists. Each has been lastingly influenced by his early environment, Sukarno by the mystique of Javanism, subtly blended with nationalism and Marxism, Hatta by the churnings of rapid cultural change in his home society in which a dynamic individualism and spirit of entrepreneurship have come to predominate. For the adherent of Javanism that island's historic glory prior to the coming of the colonial era provides the centripetal force in public life, further bolstered by an aggressive nationalism that sees Indonesia as one country, from the tip of Sumatra to Western New Guinea, or from "Sabang to Merauke" as Sukarno so frequently has put it. For the Menangkabau, far from Java, conscious of local traditions and proud of local achievements, Javanism is a new form of colonialism; 


\section{JUSTUS M. VAN DER KROEF}

the Indonesian state for him needs to give recognition to ethnic and local particularism as embodied in the motto of the great seal of the Republic: Bhinneka Tunggal Ika- "One out of Many."

Ever since Indonesia formally obtained its independence at the close of 1949 the lack of a clearly defined relationship between the central government in Djakarta and the daerah, as the outlying provinces and districts are commonly called, has been a major malady. Through the years the chorus of voices coming from the daerah complaining of neglect by Djakarta has risen in volume. The undertone has always been the same: the lack of meaningful fiscal autonomy on the part of the outer territories, resulting in an alleged "draining process" in which the valuable commercial crops cultivated in the daerah are exported under central government control and the latter keeps the lion's share of the proceeds for its own use. To this must be added a newly entrenched ethnic antagonism: the national government's oversize bureaucracy, so it is alleged, consists principally of Javanese, while "sons of the daerah" are helpless to prevent the alarming spread of public administrative corruption, inefficiency, and lack of productivity in the government. Rightly or not daerah inhabitants, who, as they so frequently put it, feel themselves "djauh dari pusat" (far from the centre, i.e., Djakarta) have come to look upon themselves as energetic, resourceful folk, whose progress and the progress of their territory is stifled by the parasitic and over-centralised national government " run by Javanese."

It would not be difficult to marshal impressive proof for the daerah's case. Indonesia as yet awaits an adequate and comprehensive local government law defining the scope of authority of each unit of government. The civil service has in fact grown enormously, from about 140,000 at the close of the colonial era to nearly one million in $1955 .^{3}$ The daerah can demonstrate that they are carrying a disproportionately heavy burden of the requisite fiscal contributions. For example, Indonesia depends for at least 60 per cent. of its total government revenue on receipts from taxes in the import-export sphere of the economy; in 195546 per cent. of Indonesia's total export income came from the exports of rubber and 70 per cent. of all rubber exported from Indonesia is cultivated outside Java, principally in Sumatra. The daerah feel that in return for such contribution they do not receive a commensurate allotment from the national government for local development purposes; indeed daerah spokesmen are almost to a man in agreement

s Java Bode (Djakarta), February 4, 1955. 
with the view of the Central Sumatran junta that rose against Djakarta in December 1956 that government " centralisation needs to be abolished since this system leads only to an unsound bureaucracy, corruption, stagnation of reconstruction in the daerah, and loss of initiative and control." " Finally, spectacular cases of corruption in the central government, involving cabinet ministers, civil servants, and judges, have tended to heighten the dissatisfaction even more. In this dissension former Vice-President Hatta has become the chief exponent of daerah autonomy, particularly in Sumatra, the island from which he hails. Hatta has praised the movements in various parts of Sumatra designed to give greater autonomy to the various ethnic regions as an expression of "the will to reconstruction" and has noted that between the daerah and the capital there are "principal differences." $s$ While he has not as yet expressed himself in favour of a federal state in Indonesia, it is clear that he sees no solution to Indonesia's present difficulties until the provincial autonomy issue has been settled.

President Sukarno, and his hand-picked premier, planning expert Djuanda, on the other hand, appear to favour a state in which public administrative emphasis falls on centralised unity, and their views find favour in such influential parties as the Partai Nasional Indonesia (National Indonesian Party-PNI) and the Partai Kommunis Indonesia (Indonesian Communist Party-PKI). For Sukarno, as has been pointed out, the national indivisibility of the Indonesian state which he helped to create is a mystic ideal, supported by a sense of the historic mission of Javanism and by modern egalitarian nationalism. For Djuanda, preservation of national unity is above all an economic necessity. The great diversity of islands of which the Indonesian Republic is composed, makes, in the words of the premier, for "plus as well as minus areas," i.e., regions with sufficient or more than sufficient resources to stand by themselves and regions that are " underdeveloped" and that are entitled to the assistance of the central government. Underlying this view is the conviction that Indonesia desperately needs some programme of co-ordinated development, implemented by a central overcapping agency of government, lest "the poor regions become poorer and the rich even richer," so that ethnic and provincial jealousies and hostilities would be amplified even further. It is not that Djuanda and Sukarno oppose

4 Ibid., December 22, 1956.

5 Ibid., June 27, 1957.

- Ibid., April 26 and 29, 1957. 


\section{JUSTUS M. VAN DER KROEF}

a measure of provincial autonomy-their approval of recent proposals looking toward an increase in the number of districts and provinces in Sumatra and East Indonesia is indicative of that--but they differ from many daerah leaders in the degree of autonomy envisaged for the provinces. There can be little question that they oppose the return of a federal state in Indonesia as it existed in the first months of Indonesia's national independence between December 1949 and April 1950, and large-scale recent arrests of political figures favouring such a state shows that Sukarno and others mean to stop resurgent federalism at all cost. This is also evident from Sukarno's and Djuanda's determination to crush by all possible military action the recent proclamation of the establishment of a rival "Republic of Indonesia " in Sumatra.

Yet the idea of the federal state has made much headway in recent months, not only in the areas controlled by or sympathetic to the rival Sumatran Republic, but also in regions like Kalimantan (Borneo) and Nusa Tenggara (Lesser Sunda islands) regarded as loyal to Djakarta.

The issue is, unfortunately, obscured by the colonial antecedents of the federal concept in Indonesia. It had long been one of the cornerstones of Dutch colonial policy that Indonesia is a nation of nations, a conglomeration of incredibly divers ethnic groups and minorities, with their own traditions and level of development. When the Dutch, during the Indonesian Revolution, came to the realisation that the days of their old order were numbered, they bent their efforts to construct in Indonesia a federal state composed of nearly autonomous separate provinces and territories, and it was to such a state that they transferred their sovereignty over their East Indian possessions in the closing days of 1949. But to Sukarno and other nationalist figures the federal idea smacked of the divide and rule policy of traditional Dutch colonialism. In the course of 1950 the component states of federal Indonesia, sixteen in all, " merged" with Java into a unitary state. The procedure of unification in retrospect seems summary, relying on hastily constructed plebiscites and ignoring constitutional procedures. ${ }^{7}$ Violent resistance to the merger process broke out in Eastern Indonesia, but the national government was able to break the opposition. Yet as early as 1950 criticisms of the excessive centralisation of government could be heard, culminating in the rebellions throughout Sumatra, Borneo, and Eastern Indonesia

7 F. R. Böhtlingk, “De Nieuwe Eenheidsstaat," Indonesië (The Hague), Vol. 4 (1950), pp. $106-118$. 
beginning in December 1956, and the establishment in those areas of local councils of government, backed by territorial army commanders, which have for practical purposes been able to defy the central government. To permit the daerah to return to something very much like the state of autonomous federalism would be tantamount to admitting the mistake of the unitary state, and of its chief architect, Sukarno, and few observers of the Indonesian scene are prepared to concede that as a likely possibility.

The problem becomes more pressing as the national economy seems to worsen. The movement for more autonomy in the daerah is supported by dynamic entrepreneurial elements in the developing business community, anxious to liberalise their commercial and investment opportunities and chafing under the mountain of restrictions and regulations coming from Djakarta. The daerah are, so to speak, a "frontier" society, less densely populated by far than overcrowded Java, where structural deficiencies in agriculture and industry hamper a more rapid growth. ${ }^{8}$ In Java underemployment in the peasant society seems to be increasing, and in the absence of an expanding economy government service has become an avenue of employment of ever greater importance for the skilled and educated.' To daerah leaders Java's socio-economy seems thus to become more and more parasitic and its political complexion increasingly radical, so that the entire course of the country's future development is felt to be threatened. A parasitic Javanism, steeped in the mystique of an uncritical nativistic nationalism and supported by the frustrations of an impoverished mass prone to espouse extreme causes, is perhaps the heart of the antithesis Sukarno-Hatta.

\section{II}

In economic life this antithesis is obscured by the marked preference toward Socialistic planning in the outlook of both leaders. Sukarno's admiration for a collectivised economy is of long standing, and has been reiterated in countless addresses denouncing "free fight liberalism" and lauding gotong rojong and "shared production and prosperity." Hatta has similar inclinations. He was the chief author of the "economic clause" in Indonesia's

B J. M. van der Kroef, "Social Structure and Economic Development in Indonesia," Social Research (New York), Vol. 26 (1956), pp. 394-418.

9 Clifford Geertz, The Development of the Javanese Economy: A Socio-Cultural Approach (Center for International Studies, Massachusetts Institute of Technology, Cambridge, Mass., 1956). 
provisional constitution (article 38, subs. 1-3), prescribing that "branches of production of importance to the state and which vitally affect the life of the people, shall be controlled by the state," while state control also extends itself to "land and water and the natural riches contained therein." Moreover, Hatta is the father of the co-operative movement in the new Indonesia and his tireless efforts on its behalf, especially among the impoverished peasantry and petty industrialists, are especially noteworthy. Yet, there are important differences between the two men on this point.

Hatta, especially in the last two years, appears to have become much less doctrinaire in his views of the country's economic development and his sympathy for the rising entrepreneurial groups in the daerah, whose energy and business acumen are often ignored in foreign reports on Indonesia, is unmistakable. Hatta has also been vociferous in his criticism of recent policies of preferments for a small group of selected (usually Javanese) businessmen, which have led to an unprecedented spread of graft and bribery. With the laudable intent of encouraging a domestic Indonesian merchant and industrial class a handful of Indonesian businessmen were given special credits and licences to import and export necessary goods. Being unable to make effective use of these preferments the businessmen in question resold licences to established Chinese and European firms or went into fictitious partnerships with them, while pressing for additional benefits from underpaid government officials, who were soon in league with them. Political and business figures, most often associated with Sukarno's thinking on the need to "Indonesianise" the economy as quickly as possible, have defended all these nefarious practices on the grounds that they are a step towards giving the country's economy a truly national character. But the havoc in inflation, black market speculation, depletion of foreign exchange reserves, and widespread corruption that such policies have contributed to has drawn the lines of battle between the two opposing camps in economic development in Indonesia ever more clearly. Basically, the clash is between a pragmatic economic policy, guided by an orthodox economic rationale in fiscal management, and a more dogmatic approach in which nationalistic and socialistic policy principles receive primary consideration.

In the former school the emphasis falls perhaps on a careful husbanding of Indonesia's resources and on the need to increase productivity. Protagonists of this approach are apt to point out that, in common with some other underdeveloped countries, 
Indonesia's economic health depends very heavily on a few agricultural and mineral exports, and that there has been a tendency for one or two products to take up an increasing share of the nation's total export income. For example, in 1938 rubber exports provided 22.6 per cent. of Indonesia's total export income; in 1954 this figure had risen to 30.9 per cent. and in 1955 to 46.0 per cent. For petroleum and petroleum products the respective percentages in the same years are 23.8 per cent., 26.4 per cent. and 22.8 per cent.; for tin and tin ore 5.0 per cent., 7.2 per cent. and 6.4 per cent. All other exports from Indonesia (e.g., coprah, tea, palm oil and palm kernels, tobacco, sugar, and forest products) have consistently and markedly remained below their pre-war percentages. Moreover, Indonesia's production of only two exports, rubber and petroleum, have fairly steadily increased since the last year before the second world war, while all other major products, including minerals like coal and bauxite, show either severe fluctuations or a decline. It must also be noted that despite the production increase of crude petroleum Indonesia's share in world petroleum production has dropped in consequence of the considerable growth of the latter between 1938 and 1955, and that because of the unsettled political situation in the past two years rubber production has diminished too. ${ }^{10}$

Lack of planning and of judicious allocation of foreign exchange earnings from the export of commodities like rubber-always subject to severe fluctuations in world demand-have led to a steady drop in such earnings over the years, and according to a recent pronouncement of Finance Minister Sutikno Slamet gold reserves have fallen from (\$ U.S.) 511 million in 1951 to about 158 million at present. At the same time the government has resorted to the printing press to meet the demands for money and the amount of total currency in circulation grew from 3,310 million Rupiah in 1949 to 11,763 million Rupiah in June 1956. The government's deficit financing policy has contributed severely to the corroding inflation that has plagued Indonesia: the cost of living in the city of Djakarta increased at least 180 per cent. between 1952 and the present, while the price index of food in rural regions shot upward by about 100 per cent. between 1950 and 1955. Since December, 1957, when the Indonesian government forcibly took over Dutch enterprises in retaliation for Dutch

10 Ekonomi dan Keuangan Indonesia (Djakarta), Vol. 10 (1957), pp. 264, 271-272; B. H. Vlekke, ed., Indonesia in 1956. Political and Economic Aspects (The Hague, New York, 1957), pp. 55-78. See also Statistik 17 Agustus 1956. Biro Pusat Statistik (Djakarta, 1956), pp. 50-148, for production, export, and import figures. 


\section{JUSTUS M. VAN DER KROEF}

"stubbornness" in retaining West New Guinea, an area claimed by Indonesia since 1949, economic conditions have worsened even more. Despite all manner of restrictions on the import of consumer goods and notwithstanding widespread recognition that the 40-hour work week (7-hour work day) in such fields as commercial agriculture is wholly inadequate, the drift toward increased black market speculation and further inflation continues, not least because of the political problems which an austerity programme of underconsumption and increased production poses. At the same time foreign capital interests find their position all the more difficult because of continued illegal occupation of estate lands, the heavy outlay required for all manner of social obligations (e.g., compulsory premiums on the occasion of Lebaran, the end of the Muslim fasting period; educational, housing, and medical expenses for workers), and the debilitating atmosphere of xenophobia that is part of Indonesian nationalism. Foreign enterprise is further hampered by the delay in transfers of profits and credit and by unrealistic currency controls, so that many concerns are looking for investment opportunities outside Indonesia. ${ }^{11}$

One sector of articulate opinion in Indonesia views all these developments with unconcealed alarm, and the measures taken by the present Djuanda cabinet--the ban on strikes, the abolition of the official exchange rate of the Rupiah, attempts strictly to regulate imports-are regarded as ineffectual because they are not carried far enough or are contradictory to other government policies. For example, the advantages in the removal of the differential exchange rates for the Rupiah, thus allowing Indonesia's currency to "find its own level on the market," are counteracted by a continuation of strict controls over foreign trade, licensing and preferments of imports and exports, transfer of credits, and so on. The "New Life Movement" inaugurated by President Sukarno on August 17, 1957, which is designed to raise popular morale and urge a programme of austerity, hard work, and incorruptibility on the citizenry, is already being sabotaged, and influential labour organisations, such as the communist dominated SOBSI federation, have given no indication that a longer work week is part of their programme. Perhaps the best indication of the continuing economic danger is the report that the daerah persist in evading the central government's efforts to regulate foreign trade and despite repeated government measures

11 Cf. for example the annual report of the HVA Co. in Java Bode, June 17, 1957. 
continue to barter directly with other nations, bypassing the national authority and keeping their earnings for themselves. ${ }^{12}$

The second school of thought that one encounters, and which for various reasons is generally in sympathy with the particular brand of nationalism advocated by Sukarno, is not altogether blind to these economic problems. Here again the difference is a matter of emphasis. 'This school is inclined to look upon economics essentially as an adjunct of certain policy objectives inherent in the idea of Indonesian nationalism and attainable through infinite regulation and manipulation of the economic process. 7 For this group the social welfare function of the state is paramount and adherents of this approach are principally concerned with providing those educational, medical, and other services to which in their opinion the citizen of a modern state is entitled. Financing such services is a matter of secondary significance: unbalanced budgets and the inflationary pressures of deficit spending, continued borrowing from foreign agencies, fiscal manipulations, high taxes on foreign corporate enterprises and special headtaxes (recently instituted) on foreign residents of the country, all these are technical matters that have only incidental bearing on the desirability of policy objectives.

Above all, the proponents of this second approach are conscious of the structural deficiencies of the Indonesian economy in terms of its colonial past; indeed, the nefarious influence of colonialism has become for the members of this group an article of faith that requires to be repeated as preface to any analysis of their country's economy that has value in their eyes. The remnants of colonial private enterprise-the estate companies, the import-export houses, or the mining corporations-are usually viewed as undesirable anachronisms, necessary perhaps in this transitional period, but having little real future in the country unless controlled by Indonesians. "Indonesianisation" of private foreign enterprise, meaning the entry of qualified Indonesians into executive functions, is in fact but one aspect of a general policy of nationalisation. The latter includes eventual state control over important primary sources of production (e.g., mining and public utilities), but also, paradoxically, encouragement to native Indonesian mercantile and industrial groups, and critics of the second school of economic planning in Indonesia even now accuse it of having no clear understanding of a consistent socialistic programme of economic development, since private enterprise and even monopoly are being 12 Ibid., July 24, 1957. 
encouraged side by side with collectivism in agriculture and industry. ${ }^{14}$

But criticism of this type fails to consider the strong undertone of rancour and hypernationalistic xenophobia in this second approach to economic planning in Indonesia, which subordinates the economic process to ideological and policy objectives. In the ranks of organised labour in Indonesia, controlled to a large extent by communists, in the lower echelons of the civil service, among the landless rural workers, and in influential circles of academicians and intellectuals the doctrine of "nationalistic" economics finds its supporters, just as the more "classically" oriented concepts of the first economic school have their followers especially outside Java in the growing groups of rubber and coprah small holders, the entrepreneurs in transport and handicraft, in short among the embryo capitalists of the nation, supported by certain army officers, intellectuals, and a handful of the higher grade bureaucrats. To each group Hatta and Sukarno represent something in this connection: the former, more austere and intellectual, is the symbol of a rational, pragmatic, and more conventional style in public affairs and economic planning; the latter, sanguine and immersed in the mystiques of nativistic nationalism, stands for the emotion-charged levee en masse, which by its very enthusiasm can move mountains and stamp, almost by an act of will, a working economy out of the ground. Thus, restoring the dwitunggal, as one Indonesian journalist once told this writer, is not unlike seeking a fusion of ice and fire.

\section{III}

Neither Sukarno nor Hatta are communists, but their attitude towards communism markedly differs. Sukarno is convinced that western style parliamentary democracy and its party system are unsuitable for his country; instead, Indonesia should have some kind of moderate collectivism, described variously as " guided democracy" or "gotong rojong (mutual co-operation) government," under which all major political groups, nationalists, communists, and religious parties, collaborate toward the common good under the leadership of some kind of executive agency or

\footnotetext{
1 Nationalisation of foreign enterprises now is contemplated not only by the national government but also by municipalities. The city council of Djakarta decided on July 15, 1957, to " nationalise" all sizable foreign enterprises in the city, including restaurants and shops, within fifteen years. Directed ostensibly against Chinese business interests, it is expected that other municipalities will follow suit. The legal aspects of these decisions are far from clear, but have tended to heighten the feeling of insecurity in the foreign business community in Indonesia.
} 
"national council." Repeatedly, Sukarno has expressed his affection for political collectivism, he has held up Red China and Nasser's Egypt to his countrymen as examples of " a grand reconstruction," worthy of emulation, and has let it be known that during his recent world tour he learned most from his visit to "the socialist countries." Domestically Sukarno has urged incorporation of the communists in the government and abroad he has reiterated Indonesia's active " neutralism."

To Hatta, Sukarno's concept of "guided democracy" is anathema and the notion that communists, secular nationalists, and anti-communist religious parties can all collaborate is an illusion. The concept of some kind of collectivist democracy Hatta has stigmatised as the prelude to Caesarism, a reckless perpetuation of revolutionary and egalitarian thinking that can end only in tyranny. ${ }^{15}$ Moreover, for Hatta there is an unbridgeable gap between Marxism in its materialistic orientation and Islam, his own -and Sukarno's - faith, and the dominant religion of Indonesia, which has also leavened so much of its national aspirations. Because of this gap any co-operation with the communists is an impossibility. Even though Hatta still clings to the ideal of a future co-operative economy, the character of this economy must be "Indonesian," i.e., it must make room for the religious temper and traditional social mechanisms of reaching compromise inherent in native culture. Thus, on his visit to communist China in October, 1957, Hatta was at pains to point out to his hosts that "Marxism as a materialist philosophy and outlook on life is only followed by the communist movement in Indonesia," and that "there is an ideological difference between the People's Republic of China and the Republic of Indonesia," "although both countries may have an identical aim in working for popular welfare and prosperity. At home, Hatta has on occasion been less restrained by far, and has lashed out against the "irreligious ideologies" of communism, and its "international conspiratorial character."

The Sukarno view on communism is in Indonesia most commonly held by those who share the President's affection for a nationalist mystique, nativistic in character and Rousseauist in expression. Its very anti-westernism is a commendation among those who thrive on the memory of hated colonialism and among whom communism has succeeded in depicting itself as Asian

\footnotetext{
25 J. F. Rutges, " Het dispuut tussen Sukarno en Hatta," Oost en West (Amsterdam), August 1957, pp. 14-16.

16 Antara Daily Newsbulletin, October 1, 1957, p. 3.
} 


\section{JUSTUS M. VAN DER KROEF}

nationalism's staunchest ally. Above all, communism's ideological discipline and highly effective organisation appeal particularly in areas, such as Java, where rapid political and economic changes have loosened countless numbers into a turbulent stream of proletarian jetsam. In other areas of Indonesia, where the processes of social disorganisation are less severe than in densely populated Java, communism has few followers, and so communism's recent and spectacular successes in Java have tended to augment other differences between that island and other regions of the country. It is for this reason that the influential anti-communist Masjumi (Muslim) Party is so popular outside Java. Though Hatta is not formally identified with Masjumi his views have generally coincided with those of the Masjumi's left wing, particularly in international affairs. Sukarno is the titular leader of the Partai Nasional Indonesia (Indonesian National Party), long the standard-bearer of nationalism, with which until very recently the communists closely collaborated. It is on the vital communist issue that the dwitunggal again differ markedly, a difference little susceptible to compromise.

The real test of a new rapprochement between Indonesia's two great leaders now appears to have come. Hatta has emphatically dissociated himself from the Revolutionary Republic of Indonesia proclaimed on Sumatra last February, yet there can be no question where his real political sympathies lie. Though party leaders and prominent parliamentary figures have laboured hard in the past few months to find a formula whereby Hatta could return to the government, Hatta has remained aloof from a regime, the ideological as well as the constitutional nature of which he has openly questioned. After his return from his visit to the People's Republic of China last October he declined to assume the Vice-Presidential office once again, as well as an invitation to join the National Planning Board. In some circles his attitude of aloof criticism had earlier aroused resentment, ${ }^{17}$ but in the restive outer areas it met with approval. Even so some regional leaders may well have been misled as to Hatta's willingness to oppose the present state of affairs. Many observers believe that Hatta's position is now ideally suited to bring about a compromise between the rebels in Sumatra and North Celebes and the Djakarta government: Perhaps in effecting this compromise the harmony between Sukarno and Hatta, and the forces they represent in Indonesian life, could also be restored.

17 Nieuwsgier (Djakarta), May 22, 1957 (cf. editorial " Dr. Moh. Hatta "). 